\title{
POSSIBILITY OF PREVENTION OF PHOSPHORUS DEFICIT BY INTRODUCTION OF MICROBIAL PHYTASE IN FATTENING OF BROILERS ${ }^{1}$
}

\author{
M. Lukić, Zdenka Škrbić, Zlatica Pavlovski, Z. Sinovec, R. Cmiljanić2
}

Abstract: Objective of our research was to determine the efficiency of phytase in prevention of phosphoris deficit. Trial was carried out on total 2500 Arbor Acres chickens of both sexes divided into control and trial groups I, II and III. Broilers of control group were fed completely balanced forage mixtures of standard raw material and chemical composition, whereas in mixtures for trial groups of broilers through minimal corrections, reduction or complete exclusion of dicalcium phosphate, amount of available phosphorus was reduced and phytase added $(1000 \mathrm{FU} / \mathrm{kg})$. Content of phytate phosphorus was equal in all mixtures $(0.25-0.27 \%)$. Trial lasted from 1-42 days of age. During trial gain of broiler, feed consumption and feed conversion were monitored. After each period by method of random sample 6 male and 6 female chickens were taken from each group in order to determine the tibia bone strength.

Obtained research results indicate that phytase is efficient in diets with quantity of available phosphorus of $0.36 \%$ (group I). Broilers (group II) fed diets containing lower concentration of available phosphorus by half $(0,20 \%)$ compared to control $(0,41 \%)$, with addition of phytase have realized somewhat lower production results. Broilers fed diets without mineral sources of phosphorus (group III) in spite of added phytase had statistical significantly lower gain and lower feed consumption and feed conversion during trial. Results of investigation of the tibia strength indicates that tibia from boilers in group I was the firmest, whereas the same bone from boilers of group III was easiest to break, but significant differences weren't established.

It can be concluded that by adding enzyme phytase to mixtures for broilers the utilization of phytine phosphorus can be considerably increased and in this way phosphorus deficit is prevented. Also, in this way adding of inorganic phosphorus sources without damaging consequences can be reduced, provided that diet contains sufficient quantities of phytine phosphoris.

Key words: broilers, phosphorus, deficit, phytase, production results, bone strength

\section{Introduction}

In intensive poultry production which includes constant control of health, environment and nutrition the occurence of considerable deficit of phosphorus is almost impossible. However, slight deficit of phosphorus, absolute (lack of) or relative (incresed need of poultry for phosphorus) in fattening of broilers can often happen and is rather difficult to detect as problem and cause of somewhat lower consumption of food, lower gain and lower quality of bones. Diets can be balanced in regard to content of phosphorus and still not provide optimal level necessary for maximal growth of broilers and production since availability of phosphorus from different sources is very variable. Grain plant feeds and products obatained from seed (oil meal, by products in production and processing of cereals) as main ingredients of broiler diet represent special problem since two thirds of total phosphorus contained in mentioned products is in the form of phytate phosphorus with low avilability to broilers (Remus, 2005). It is known fact that monogastric animals due to the physiological lack of enzyme phytase cannot utilize well enough phytine phosphorus (Sebastian at al., 1998).

In order to supplement endogenous enzyme system in animal, increase of the utilization/availability of certain nutritious matters and/or removal of anti nutritious factors is becoming objective of research of scientistc engaged in nutrition and their attention is directed to use of exogenous enzymes in production and use of livestock feed. Use of microbial phytase leads to considerable increase in utilization of present phytine phosphorus and in this economically efficient way the phosphorus deficit is prevented without exaggerated addition of inorganic sources and indirectly the necessary quantity of phosphorus added to food is reduced as well as its excretion into environment (Denbow et al., 1995; Yi et al., 1996; Hoppe, 1992; Christensen et al., 1997).

1 Original scientific paper - supported by the Ministry of Science and Technology, Project no. TR6885B - Originalni naučni rad je finansiran od strane Ministarstva za nauku i tehnologiju Projektom broj: TR6885B

$2 \mathrm{Mr}$ Miloš Lukić, research assistant, mr Zdenka Škrbić, research assistant, dr Zlatica Pavlovski, scientific counselor, dr R. Cmiljanić, scientific counselor, Institute for Animal Husbandry, Belgrade-Zemun, dr Z. Sinovec, full professor, Faculty of Veterinary medicine, Belgrade 
Majority of researches proves and measures the efficiency of phytase in tial, more or less controled conditions and/or on relatively small number of animals. Therefore, certain researchers point out the need for additional research of the efficiency of phytase carried out in production conditions (Rosen, 2004). Objective of our research was to determine the efficiency of phytase in prevention of phosphorus deficit in conditions of broiler nutrition and production which are typical for our region.

\section{Materials and Methods}

Trial was carried out on total 2500 Arbor Acres chickens of both sexes divided into 4 groups, (control and 3 trial groups), with 5 boxes per each group and 125 chickens in each box. Broilers of control group (C) were fed completely balanced forage mixtures of standard raw material and chemical composition, whereas in mixtures for trial groups of broilers (groups I, II and III) through minimal corrections, reduction or complete exclusion of dicalcium phosphate, amount of available phosphorus was reduced and phytase added $(1000 \mathrm{FU} / \mathrm{kg})$. Content of phytate phosphorus was equal in all mixtures $(0.25-0.27 \%)$.

Trial lasted from 1-42 days of age, with three diets: starting (1-21 days), growing (22-35 days) and finishing (36-42 days) experimental diets

Raw material and chemical composition of trial mixtures is presented in table 1 .

Table 1. Composition of the starting, growing and finishing experimental diets

\begin{tabular}{|c|c|c|c|c|c|c|c|c|c|c|c|c|}
\hline \multirow[t]{2}{*}{ Ingredients, $\%$} & \multicolumn{4}{|c|}{$\begin{array}{c}\text { Starting period } \\
(1-21 \text {. Days })\end{array}$} & \multicolumn{4}{|c|}{$\begin{array}{l}\text { Growing period } \\
\text { (22-35. Days) }\end{array}$} & \multicolumn{4}{|c|}{$\begin{array}{c}\text { Finishing period } \\
\text { (36-42. Days) }\end{array}$} \\
\hline & $\mathrm{C}$ & I & II & III & $\mathrm{C}$ & I & II & III & $\mathrm{C}$ & I & II & III \\
\hline Corn & 54.7 & 53.2 & 54.9 & 54.4 & 58.4 & 58 & 58.6 & 58.5 & 62.1 & 62.3 & 62.4 & 62.6 \\
\hline Soybean meal (44\% CP) & 22 & 26 & 25 & 27 & 20 & 23 & 23 & 25 & 20 & 20 & 20 & 20 \\
\hline Sunflower m. (33\% CP) & 3 & 2 & 2 & 0 & 3 & 2 & 2 & 0 & 5 & 5 & 5 & 5 \\
\hline Sunflower m. (44\% CP) & 5 & 5 & 4 & 5 & 5 & 5 & 4 & 5 & 5 & 5 & 5 & 5 \\
\hline Fodder yeast & 5 & 5 & 5 & 5 & 4 & 4 & 4 & 4 & 0 & 0 & 0 & 0 \\
\hline Fish meal & 4 & 2 & 3 & 2 & 3 & 1 & 2 & 1 & 1 & 1 & 1 & 1 \\
\hline Fat & 3 & 3 & 3 & 3 & 3 & 3 & 3 & 3 & 3 & 3 & 3 & 3 \\
\hline Fodder chalk & 0.5 & 1 & 1.8 & 2.3 & 0.5 & 0.9 & 1.8 & 2.2 & 0.9 & 1.2 & 1.6 & 1.9 \\
\hline Dicalcium phosphate & 1.5 & 1.5 & 0 & 0 & 1.8 & 1.8 & 0.3 & 0 & 1.5 & 1 & 0.5 & 0 \\
\hline Salt & 0.3 & 0.3 & 0.3 & 0.3 & 0.3 & 0.3 & 0.3 & 0.3 & 0.5 & 0.5 & 0.5 & 0.5 \\
\hline Vit. - min. mix & 1 & 1 & 1 & 1 & 1 & 1 & 1 & 1 & 1 & 1 & 1 & 1 \\
\hline Phytase, $1000 \mathrm{FU} / \mathrm{kg}^{1}$ & - & + & + & + & - & + & + & + & - & + & + & + \\
\hline Total: & 100 & 100 & 100 & 100 & 100 & 100 & 100 & 100 & 100 & 100 & 100 & 100 \\
\hline Crude protein $(\mathrm{CP})$ & 22.2 & 22.3 & 22.2 & 22.2 & 20.5 & 20.3 & 20.5 & 20.5 & 18.3 & 18.3 & 18.3 & 18.4 \\
\hline $\mathrm{ME}, \mathrm{MJ} / \mathrm{kg}$ & 12.7 & 12.6 & 12.7 & 12.7 & 12.8 & 12.8 & 12.9 & 12.9 & 12.8 & 12.8 & 12.8 & 12.8 \\
\hline Calcium & 1.01 & 1.07 & 1.03 & 1.03 & 1.01 & 1.03 & 1.02 & 1.03 & 0.93 & 0.90 & 0.91 & 0.89 \\
\hline Total phosphorus & 0.85 & 0.79 & 0.55 & 0.46 & 0.85 & 0.79 & 0.55 & 0.46 & 0.71 & 0.62 & 0.53 & 0.45 \\
\hline Available phosphorus & 0.41 & 0.36 & 0.20 & 0.11 & 0.41 & 0.36 & 0.20 & 0.13 & 0.29 & 0.22 & 0.16 & 0.10 \\
\hline Phytate phosphorus & 0.25 & 0.25 & 0.25 & 0.25 & 0.25 & 0.25 & 0.25 & 0.24 & 0.27 & 0.27 & 0.27 & 0.28 \\
\hline
\end{tabular}

${ }^{1}$ Phytase Novo CT

Ggain, feed consumption, and feed conversion were monitored during trial. After each period by method of random sample 6 male and 6 female chickens were taken from each group in order to determine the tibia bone strength. Breaking force was measured on apparatus IPNIS and expressed in kilograms necessary for bone to be broken (Mašić et al., 1985). Based on relation between breaking force and surface of tibia diaphysis section specific breaking force was calculated. 
Results and Discussion

Observed production parameters, daily gain of broilers, daily feed consumption and feed conversion (table 2), are considered reliable indicators of feed quality, especially when determining relative bioavailability of phosphorus in feed (Ravindran at al., 1995)

Table 2 . Some production parameters of broilers during trial (mean \pm standard deviation)

\begin{tabular}{|c|c|c|c|}
\hline Group & $\begin{array}{l}\text { Daily gain } \\
(\mathrm{g})\end{array}$ & $\begin{array}{l}\text { Daily feed } \\
\text { consumption }(\mathrm{g})\end{array}$ & $\begin{array}{c}\text { Feed conversion } \\
(\mathrm{kg} / \mathrm{kg})\end{array}$ \\
\hline & & $1-21$. Days & \\
\hline K & $27,43 \pm 0,58^{a}$ & $46,4 2 \longdiv { \pm 0 , 4 8 }$ & $1,70 \pm 0,03^{\mathrm{a}}$ \\
\hline I & $26,91 \pm 0,53^{a}$ & $46,49 \pm 0,50$ & $1,74 \pm 0,02^{\mathrm{ab}}$ \\
\hline II & $27,32 \pm 0,36^{\mathrm{a}}$ & $46,45 \pm 0,51$ & $1,73 \pm 0,03^{\mathrm{a}}$ \\
\hline III & $25,74 \pm 0,58^{b}$ & $\begin{array}{l}45,72 \pm 1,25 \\
21-35 . \text { Days }\end{array}$ & $1,79 \pm 0,05^{b}$ \\
\hline K & $44,18 \pm 1,36^{\mathrm{a}}$ & $111,30 \pm 2,88^{a}$ & $2,54 \pm 0,08$ \\
\hline I & $44,11 \pm 2,08^{a}$ & $109,93 \pm 2,53^{\mathrm{a}}$ & $2,53 \pm 0,09$ \\
\hline II & $41,41 \pm 1,78^{a b}$ & $106,54 \pm 3,52^{a b}$ & $2,58 \pm 0,06$ \\
\hline III & $40,65 \pm 1,42^{b}$ & $\begin{array}{l}102,90 \pm 2,30^{\mathrm{b}} \\
\underline{35-42 . \text { Days }}\end{array}$ & $2,51 \pm 0,11$ \\
\hline K & $61,87 \pm 1,88$ & $145,60 \pm 8,51$ & $2,35 \pm 0,16$ \\
\hline I & $59,48 \pm 3,11$ & $146,28 \pm 3,10$ & $2,40 \pm 0,08$ \\
\hline II & $60,98 \pm 3,39$ & $142,62 \pm 6,01$ & $2,34 \pm 0,07$ \\
\hline III & $58,84 \pm 3,19$ & $\begin{aligned} 143,05 & \pm 7,44 \\
1 & -42 . \text { Days }\end{aligned}$ & $2,39 \pm 0,12$ \\
\hline K & $38,75 \pm 0,60^{a}$ & $83,02 \pm 1,16^{\mathrm{a}}$ & $2,18 \pm 0,03^{\mathrm{a}}$ \\
\hline I & $38,07 \pm 0,52^{a}$ & $82,80 \pm 1,27^{\mathrm{a}}$ & $2,21 \pm 0,02^{a b}$ \\
\hline II & $37,63 \pm 0,83^{a}$ & $80,74 \pm 1,76^{a b}$ & $2,19 \pm 0,03^{a b}$ \\
\hline III & $36,23 \pm 0,95^{b}$ & $79,40 \pm 1,64^{b}$ & $2,24 \pm 0,02^{b}$ \\
\hline
\end{tabular}

Obtained research results indicate that phytase is efficient in diets with quantity of available phosphorus of $0.36 \%$ (group I), which is in accordance with results stated by Huyghebaert (1997). Broilers fed diets containing lower concentration of available phosphorus by half (group II) compared to control, with addition of phytase have realized somewhat lower production results, but still in line with control group. Broilers fed diets without mineral sources of phosphorus (group III) in spite of added phytase had significantly lower gain and lower feed consumption and feed conversion during trial as consequence of phosphorus deficit in the organism.

Numerous researches measure and present in different way the efficiency of phytase, and obtained results are variable and more or less comparable. Among other things, research has demonstrated that $1 \mathrm{~g}$ of phosphorus from defluorized phosphate in diet for broilers can be replaced with approximately 800 phytine units of phytase (Denbow et al., 1995; Yi et al., 1996) and that by adding phytase to diet content of phosphorus can be reduced by approx. 30\% (Hoppe, 1992; Christensen et al., 1997), also that by adding phytase over 70\% of phytine posphorus in diet can be hydrolized (Shoner and Hope, 1993; Van der Klis et al., 1997). Majority of researchers agree that quantity of phosphorus which can be replaced by phytase depends on several factors, the most important is applied type and level of phytase and content of total and phytine posphorus in diet. Enzyme phytase it self demonstrates different reactivity depending on the conditions of application (Sebastian at al., 1998). Therefore it is important to determine and/or verify the efficiency of phytase in actual conditions of application. 
Analysis of results of investigation of the tibia strength (graph 1) indicates that tibia from boilers in group I was the firmest, whereas the same bone from boilers of group III was easiest to break, but significant differences weren't established due to the high variability of this parameter.

Graph 1. Breaking force and specific breaking force of tibia



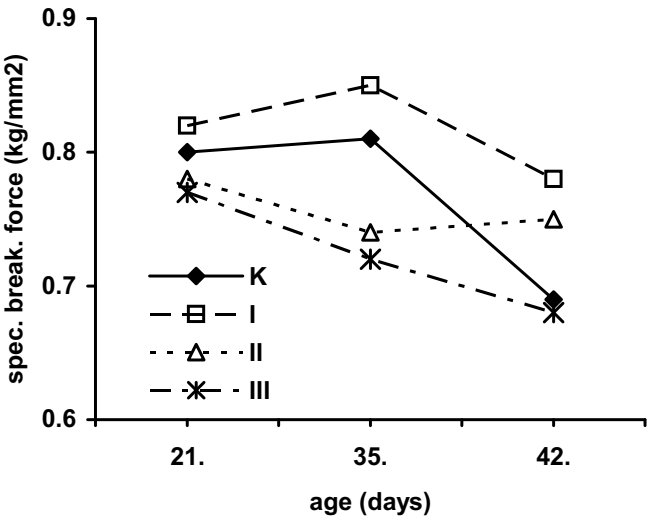

Conclusion

Considering the results obtained in this research it can be concluded that adding of enzyme phytase to mixtures for broilers the utilization of phytine phosphorus can be considerably increased. Therefore, adding of phytase can be recommended as efficient prevention of phosphorus deficit when phosphorus sources of low or variable availability are used in nutrition of broilers provided that diet contains sufficient quantity of phytine phosphorus.

Also, trial results indicate that by adding phytase it is possible to reduce inorganic phosphorus sources until certain limit without damaging consequences. Optimal Optimum results could be expected with diets in which the quantity of available phosphorus is balanced between $0,20-0,36 \%$ in starter and grower mixtures and $0,16-0,22 \%$ in finisher mixtures with addition of $1000 \mathrm{FU} / \mathrm{kg}$ of phytase.

In regard to practical application of phytase in combination with reduced amounts of inorganic phosphorus sources, die to the effect of many factors on its efficiency, previous checking of the efficiency of selected combination of factors is recommended (type and level of phytase - level of reduction of inorganic sources of phosphorus, type of diet or typical level of phytine phosphorus in diet) through biological test where it would be sufficient to monitor production parameters (body mass, gain, feed consumption) as well as reliable indicators.

\title{
MOGUĆNOST SPREČAVANJA DEFICITA FOSFORA DODATKOM MIKROBIJALNE FITAZE U TOVU BROJLERA
}

\author{
M. Lukić, Zdenka Škrbić, Zlatica Pavlovski, Z. Sinovec, R. Cmiljanić
}

\section{Rezime}

Cilj istraživanja je da utvrdi efikasnost fitaze u preveniranju deficita fosfora. Ogled je iyveden na ukupno 2500 Arbor Acres brojlera oba pola podeljenih u četiri grupe - kontrolna grupa i ogledne I, II i III Brojleri kontrolne grupe su hranjeni kompletno izblansiranim krmnim smešama standardnog sirovinskog i hemijskog sastava, dok je u smešama za ogledne grupe brojlera minimalnim korekcijama, smanjenjem ili potpunim isključivanjem dikalcijum fosfata, smanjena količina iskoristivog fosfora i dodata fitaza (1000 
FU/kg). Sadržaj fitatnog fosfora je bio jednak u svim smešama (0.25-0.27\%). Ogled je trajao od 1-42 dana uzrasta. Tokom ogleda, prirast pilića, konverzija i utrošak hrane su praćeni. Nakon svakog perioda metodom slučajnog uzorka 6 muških i 6 ženskih pilića je izdvojeno iz svake grupe kako bi se odredila jačina tibije.

Dobijeni rezultati istraživanja ukazuju da je fitaza efikasna u obrocima gde je količina dostupnog fosfora $0.36 \%$ (grupa I). Brojleri (grupa II) hranjeni obrocima koji su sadržavali nižu koncentraciju fosfora $(0,20 \%)$ u odnosu na kontrolnu grupu $(0,41 \%)$, uz dodatak fitaze su ostvarili nešto niže proizvodne rezultate. Brojleri hranjeni obrocima bez mineralnog izvora fosfora (grupa III), i pored dodate fitaze su imal statistički signifikantno slabiji prirast i lošiju konverziju hrane tokom ogleda. Rezultati istraživanja jačine tibije pokazuju da je tibija kod brojlera iz grupe I bila najčvršća, dok je ista kost kod brojlera iz grupe III najlakše lomljena, ali signifikantne razlike nisu utvrđene.

Može se zaključiti da se aditiranjem enzima fitaze u smeše za brojlere može značajno povećati iskoristivost fitinskog fosfora, a time do određene granice $\mathrm{i}$ efikasno prevenirati deficit fosfora $\mathrm{i} / \mathrm{ili}$ umanjiti aditiranje neorganskih izvora fosfora bez štetnih posledica, pod uslovom da obrok sadrži dovoljne količine fitinskog fosfora.

Ključne reči: brojleri, fosfor, deficit, fitaza, proizvodni rezultati, jačina kostiju

\section{References}

1. CHRISTENSEN, L., BECH, L., OHMAN, A., PETTERSSON, D. (1997): Devalopment, production and performance of microbial phytases. Proceedings 11th European Symposium on Poultry Nutrition, Faaborg, Denmark, 24-28 august, 203-210.

2. DENBOW, D.M., RAVINDRAN, V., KORNEGAY, E.T., YI, Z., HULET, R.M. (1995): Improving phosphorus availability in soybean meal for broilers by suplemental phytase. Poultry Science, 74, 1831-1842.

3. HOPPE, P.P. (1992): Überblick über die biologischen Wirkungen und die ökologische Bedeutung der Phytase beim Schwein. Aus Forschung und Praxis, Ausgabe 30, BASF, 3-15.

4. HUYGHEBAERT, G. (1997): Effect of microbial phytases on phosphorus utilization. Proceedings $11^{\text {th }}$ European Symposium on Poultry Nutrition, Faaborg, Denmark, 24-28 August 1997, 220-235.

5. MAŠIĆ, B., ANTONIJEVIĆ, N., VITOROVIĆ, D., PAVLOVSKI, Z., MILOŠEVIĆ, N. and JASTŠENJSKI, S. (1985): Prilog određivanju čvrstoće kostiju pilića. Peradarstvo, 8/9, 19-24.

6. RAVINDRAN, V., KORNEGAY, E.T., POTTER, L.M., OGUNABAMERU, B.O., WELTEN, M.K., WILSON, J.H., POTCHANAKORN, M. (1995): An evaluation of various response criteria in assessing biological availability of phosphorus for broilers. Poultry Science, 74, 1820-1830.

7. REMUS, J., (2005): Poultry and environment reap the benefits of new-generation phytase. Feed Tech, $9,5,22-25$.

8. ROSEN, G. (2004): Admixture of exogenous phytases and xylanases in broiler nutrition. XXII World's Poultry Congress, Istanbul, Turkey, 8-13 june 2004 (full text electrically published in Participant list and Fulltext CD).

9. SCHONER, F.J., HOPPE, P.P. (1993): Phosphorus balance in laying hens feed Aspergilus niger phytase. Proceedings 9th European Symposium on Poultry Nutrition, Poland, 5-9. September, 494.

10. SEBASTIAN, S., TOUCHBURN, S.P. and CHAVEZ, E.R. (1998): Implications of phytic acid and supplemental microbial phytase in poultry nutrition: a review. World's Poultry Science Journal, Vol. 54: 27-47.

11. VAN DER KLIS, J.D., VERSTEEGH, H.A.J., SIMONS, P.C.M., KIES, A.K. (1997): The eficacy of phytase in corn-soybean meal-based diets for laying hens. Poult. Sci., 76, 1535-1542.

12. YI, Z., KORNEGAY, E.T., RAVINDRAN, V., DENBOW, D.M. (1996): Improving phytate phosphorus availability in corn and soybean meal for broilers using microbial phytase and calculation of phophorus equvivalency values for phytase. Poultry Science., 75, 240-249. 